\title{
NARRATIVE REVIEW: KOMBUCHA'S POTENTIAL AS A RAW MATERIAL FOR HALAL DRUGS AND COSMETICS IN A BIOTECHNOLOGICAL PERSPECTIVE
}

\author{
Firman Rezaldi ${ }^{1}$, Aris Ma'ruf ${ }^{2}$, Fernanda Desmak Pertiwi ${ }^{3}$, Nisa Siti Fatonah ${ }^{4}$, \\ Retna Yulrosly Ningtias ${ }^{5}$, M.Fariz Fadillah ${ }^{6}$, Heny Sasmita ${ }^{7}$, Ucu Wandi Somantri ${ }^{8}$ \\ Pharmacy Study, Mathla'ul Anwar University ${ }^{1,2,3,4,5}$ \\ Food Technology Study, Mathla'ul Anwar University ${ }^{6}$ \\ Public Health Study, Mathla'ul Anwar University ${ }^{7,8}$ \\ Correspondence Author: firman@unmabanten.ac.id
}

\begin{abstract}
Kombucha which is efficacious as a source of antioxidants, antibacterial, and anticancer, and alcohol content below $1 \%$ deserves to be developed as a raw material for halal drugs and cosmetics in the perspective of biotechnology that underlies the bioinformatics side and gene expression as the initial topic in designing it. The purpose of this review study is to further ensure the feasibility of kombucha as a raw material for halal cosmetics from various supporting scientific findings. The results of the study show that the potential of kombucha as a source of antioxidants, antibacterial, and anticancer agents requires further modification as an opening to prove that it is halal in silico, in vitro, and in vivo from a biotechnology perspective. The development of kombucha as a raw material for halal-standard medicines and cosmetics requires serious research collaboration from biotechnologists engaged in medicine, pharmacy, agriculture, nutrition science, and food technology.
\end{abstract}

Keywords: Drug, Cosmetic, Halal

Abstrak: Kombucha yang berkhasiat sebagai sumber antioksidan, antibakteri, dan antikanker, dan kadar alkohol dibawah 1\% layak dikembangkan sebagai bahan baku obat dan kosmetik halal dalam perspektif bioteknologi yang mendasari dari sisi bioinformatika dan ekspresi gen sebagai topik awal dalam mendesainnya. Tujuan dari kajian review ini adalah untuk lebih memastikan mengenai kelayakan kombucha sebagai bahan baku kosmetik halal dari berbagai temuan ilmiah yang menunjang. Hasil kajian menunjukkan bahwa potensi kombucha sebagai sumber antioksidan, antibakteri, dan antikanker dibutuhkan modifikasi lebih lanjut sebagai pembuka untuk membuktikan secara in silico, in vitro, dan in vivo yang halal dalam perspektif bioteknologi. Pengembangan kombucha sebagai bahan baku obat dan kosmetik terstandar halal dibutuhkan kolaborasi riset yang serius dari para bioteknolog yang bergerak dibidang kedokteran, farmasi, pertanian, ilmu gizi, dan teknologi pangan.

Kata Kunci: Obat, Kosmetik, Halal 
INTRODUCTION

Drugs and cosmetics are one of the pharmaceutical preparations that are a priority both to be produced on a large scale, used by the public at large to provide good pharmacological effects, and standard value through research results that have been clinically tested, labeled BPOM, and also labeled halal from a raw material. Halal drug and cosmetic raw materials certainly need to be developed from various sides and even research that is long enough to be standardized to the maximum. The raw materials of drugs and cosmetics that have been circulating need to be developed also through biotechnological approaches that can support the health side, especially immunity in the COVID-19 pandemic where the number of patients from COVID-19 is still relatively high in the world according to WHO data since April 2021 and has reached 131,020,967 people (Rezaldi et al., 2021), while in Indonesia has reached $1,534,255$ and experienced an increase in the number of patients as many as 6,731 people (Adnan et al., 2020).

Raw materials of halal drugs and cosmetics that need a lot more support even attention specifically in a biotechnological perspective that is quite potential one of them is kombucha. Kombucha is one of the conventional biotechnological products, probiotic,tea-based and produced through fermentation methods. The properties that can be obtained from fermented tea include as a source of antioxidants (Gaggìa et al., 2019), as a source of antimicrobials (Kapp \& Sumner, 2019), as an anticancer source (Villarreal-Soto et al., 2019), as a source of antiolesterol (Adriani et al., 2011), as an antidiabetic source (Zubaedah et al., 2019) and as a source of immunomodulators (Zubaedah et al. 2021), and Antihypertensive (Khaerah \& Akbar, 2019), so that the properties contained in these products have the potential to be developed as raw materials in the manufacture of drugs and halal cosmetics from a biotechnological perspective that need to involve from the method in silico or more widely known as bioinformatics, in-vitro in biotechnology in the form of gene expression or better known as the initial method of a research. Which serves as a screening to provide a basic foundation in strengthening the further stages of in-vivo which involves many high standard and accurate test animals.

Current or modern biotechnological methods such as bioinformatics that lead to in silico approaches, more direct gene expression in vitro, and the use of test animals that lead in vivo are the parts that play an important role in producing halal drug raw materials of pharmacopoeia standard, and halal cosmetic raw materials that are standardized in SNI (Indonesian National Standard) after passing the test or evaluation of physical preparations of each pharmacopoeia standard. g potentially as its raw material. The contents of organic chemical compounds contained in kombucha, so that it can be developed as raw materials for halal drugs and cosmetics include lactic acid, acetic acid or vinegar acid, malic acid, oxalic acid, glunic acid, butyric acid, nucleic acid, amino acids, enzymes, polyphenols and vitamins (Firdaus et al., 2020). 
Speaking about the raw materials of halal drugs and cosmetics based on kombucha in the perspective of biotechnology, it also takes one of the literacy that fully supports the status of its idolatry in the perspective of Islam which is the majority more prioritizes aspects of idolatry both in terms of therapy and the use of cosmetics in accordance with its sharia. This is in accordance with the ijtihad statement, namely the Fatwa of the Indonesian Ulema Council Number: 10 of 2018 concerning food and beverage products that contain alcohol or ethanol less than $0.5 \%$ in the halal category, so it is safe to be used in medical interests both for medicinal raw materials and halal cosmetics.

Departing from the background descriptions above, on this occasion the author will explain the potential of kombucha which has a high chance to be developed as a standard halal drug and cosmetic raw material in a biotechnological perspective through various methods of bioinformatics working principles in the form of digital molecular simulations leading in silico, molecular biology such as measurement of gene expression leads in vitro, And the selection of test animals is of a standard in producing information on the effects of drugs to the body or known as pharmacodynamics, and body effects to drugs or better known as pharmacokinetics.

\section{METHOD}

The method or approach that is done is in the form of literature studies. The data obtained comes from journal articles, proceedings, and conferences, decisions / fatwas and official websites that have relationships or keywords that are in accordance with the topic of study. Data searches are conducted through online instruments using Pubmed, Sciencedirect and Google scholar. Searches are conducted using the keywords "halal", "kombucha", "medicine", and "cosmetics". Further searches are done manually on bibliography that supports relevant writing.

\section{RESULT AND DISCUSSION}

\section{Urgency Of Kombucha As A Raw Material For Halal Drugs And Cosmetics}

Kombucha is one of the conventional biotech products of probiotics produced through fermentation techniques. Alcohol produced during the fermentation process at the lowest or below $1 \%$ is one of the services assisted by yeast, especially from the species Saccaromyces cerrevisae. The yeast species is capable of producing alcohol in anaerobic conditions. Alcohol produced through the fermentation process by S. cerrevisae certainly uses sugar as a substrate or nutrient (Pratiwi and aryat, 2012). For 7 to 14 days which is the ideal time in the kombucha fermentation process. The level of alcohol that has a halal category in kombucha has been widely supported by various findings or research so that it is safe in the manufacture of raw materials for halal drugs and cosmetics.

The results of a study conducted by Herwin et al., 2013 regarding the alcohol content produced by kombucha is about $0.0627292 \%$. The results of research conducted by Jakubczyk et al., 2020 regarding the alcohol content produced by kombucha is about 0.2- 
$3.5 \%$. The results of research conducted by Tan et al., 2020 regarding the alcohol content produced by kombucha is about $0.06-1.95 \%$. The results of research on alcohol levels in kombucha produced by several recent researchers previously there is a maximum threshold that needs to be considered in maintaining its idolatry status. The thing of concern in providing solutions at the maximum threshold related to alcohol levels produced by kombucha is through the technique of decreasing alcohol levels.

Dilution techniques, heat pasteurization, and filtering techniques on some alcoholproducing combucha microbes, and alcohol distillation. The method or all four techniques aim to lower the alcohol content in kombucha. The statement is supported by the results of research conducted by Kim \&Adhikari, 2020, namely the halal standard kombucha alcohol content of about $0.5 \%$, so that it is of high nutritional value, and also produces good pharmacological effects for the body, especially in improving immunity in the Covid-19 pandemic where variants or mutations have been widely improved while vaccines that have been widely used need evaluation from the bioinformatics side or so-called bioinformatics. Immunoinformatics is primarily in detecting polymorphisms in asians, Europeans, and Africans that have their own characteristics (Vita et al., 2015).

\section{Raw Materials Of Kombucha-Based Halal Drugs And Cosmetics As A Source Of Antioxidants}

One element of a chemical compound that has one unpaired electron is known as a free radical (Rudiana et al., 2021). These chemical compounds contained in the body can ideally be formed by means of metabolic results derived from the outer body (Parwata, 2016). Lipids, lipoproteins, starches, DNA, and RNA are parts of cells and molecules that can potentially be attacked by chemical compounds or so-called free radicals (Sayuti \&Herina, 2015). The occurrence of infection or malignancy, narrowing of blood vessels or what has been known as astheoclerosis are the parts that have an important role as the cause of damage caused by free radicals that have the potential to attack both at the cellular and molecular levels. Other disease problems that occur due to free radical attacks include the lungs, kidneys, liver, blood sugar and cataracts (Khaira, 2010).

Utilization of antioxidant compounds has been widely researched both centered on the field of food, medicine (Mangella et al., 2011), and cosmetics. Free radicals can be controlled by an antioxidant because it has the potential to protect the body from attack (Wahdaningsih et al., 2011). Kombucha has vitamin C content that is useful as a source of antioxidants. The statement has been supported by the results of research conducted by Pure et al., 2016, concluding that kombucha made from black tea contains phenol compounds. High phenol compound content is one source of antioxidants in kombucha. This statement has been supported by the results of research conducted by Nguyen et al., 2015, has concluded that probiotic bacterial cultures mixed with Lactobacillus sp have antioxidant activity in fighting free radicals. Free radical compounds attacked by kombucha can certainly prevent damage to other important organs through molecular mechanisms or so-called biotransformations. 
Biotransformation is one of the molecular mechanisms in kombucha that acts as an antioxidant where it is characterized by an increase in phenol compounds that occur due to microbial metabolism during the fermentation process (Goh et al., 2012) and utilize enzymes in a plant cell so that it has the ability to change the group of functional compounds in it (Jayabalan et al., 2008) derived from its raw materials. The raw materials that have long been known for the manufacture of kombucha are basically black tea, green tea, or leaves, fruit, flowers that contain quite good polyphenol compounds.

The fermentation process of yeast kombucha has the ability to produce the enzyme vinyl phenol reductase. The statement in the form of research results that have been done by Shaidi and Narzck mentions that the utilization of enzymes (Suhardini et al., 2016) ferulic phenol reductase will ideally synthesize phenols that have an impact on the process of decarboxylation of sinamic acid and firulat acid. Sinamic acid is a phenol group compound that plays an important role as a natural source of antioxidants for plants (Suranto, 2011). Ferulat acid is a group of sinamic hydroxy acids contained quite abundantly in the cell wall of inner plants and is an antioxidant (Hasan et al., 2013).

\section{Raw Materials Of Kombucha-Based Halal Drugs And Cosmetics As A Source Of Antimicrobials}

Kombucha on the other hand also has the potential as an antibacterial, especially in pathogenic bacterial bacteria that have been widely known to cause infection, namely Escherichia coli is a gram negative bacterium and Staphylococcus aureus is a gram positive bacteria. The two types of bacteria are normal flora that are pathogenic and both bacteria have been widely resistant to antibiotics in the market, causing major problems in terms of therapy or treatment. The statement is supported by research conducted by Chofidah et al., 2019, It concluded that the combucha fermentation of rosella flowers (Hibiscus sabdariffa L.) has bacterial inhibition at a concentration of $40 \%(\mathrm{~g} / \mathrm{v})$ characterized by the formation of a bland zone against escherichia coli and staphylococcus aureus bacteria. Another study conducted by Vohra et al., 2019, concluded the antimicrobial properties in black tea with a white sugar substrate showed the best medium in inhibiting microbes in the kombucha fermentation process within 14 days.

The content in kombucha that acts as an antibacterial in the form of organic acids is a type of acetic acid. This has been demonstrated by the results of research conducted by AlKalifawi (2014), concluded that black tea-based kombucha has the ability to inhibit the growth of pathogenic bacteria such as Escherichia coli, Staphylococcus aureus, and Pseudomonas aeruginosa. The potential of kombucha as an antimicrobial as has been conveyed in the results of previous research, does not rule out the possibility to be developed again in the pharmaceutical field, especially in producing raw materials for drug and cosmetic manufacture. 
The results of research conducted by Khaleil et al., 2020 stated that kombucha made from black tea, green tea, and also stone guava juice has the ability as an antimicrobial both in fungi speesies Altenaria sp, Aspergillus flavus, Fusarium oxysprorium, Tricoderma sp and bacteria from acinobacter sp 1 species, Acinobacter sp 2, E. coli, Klebsiella pneumonia, Klebsiella sp 2, Pseudomonas sp 1, Pseudomonas sp 2, Proteus sp, Staphyloccocci (coangulase, and Staphylococci MRSA) with different bland zones.

Kombucha has higher antibacterial activity in positive gram bacteria than negative. This is because secondary metabolites produced by kombucha have the ability to damage peptidoglycans on bacterial cell walls, as well as peptidoglycan components in gram-positive bacteria are higher when compared to peptidoglycans in gram-negative bacteria. So it is more easily damaged by kombucha as an antimicrobial agency. This can be drawn as a conclusion that peptidoglycan components on bacterial cell walls are more easily damaged by secondary metabolites in plants and microbes. The results of another relevant study conducted by Borkani et al., 2016, concluded that kombucha has higher antibacterial activity in grampositive bacteria especially from S. aureus species. The results of the study are also in accordance with the results of research conducted by Yanti et al., 2020, concluded that Kombucha made from soursop leaves has antibacterial activity that has benefits as a health drink. The results of the study have been produced to have the highest activity value by using soursop leaves and $20 \%$ sugar. The resulting bland power value was 16.28 in E.coli bacteria as gram negative bacteria, and $17.08 \mathrm{~mm}$ in $\mathrm{S}$. aureus bacteria as gram positive bacteria.

\section{Raw Materials Of Kombucha-Based Halal Drugs And Cosmetics As An Anticancer Source}

Chemopreventive is one of the efforts in controlling various types of cancer first by using diverse natural ingredients and combined with the appropriate phytochemical character, so that the utilization of kombucha combined with the appropriate phytochemical character does not produce any side effects in cancer prevention. Kombucha has been widely claimed to have anti-cancer properties for many years. This has been revealed based on the testimony and experience of someone who is a collection or population of academics who have conducted the results of their research at the study center and research institute of Russian oncology (Dufresne and Farnworth 2000).

The results of research conducted by Cetojevic et al., 2008, concluded that kombucha based on black tea and Satureja montana has antiproliferation activity in hela cells, Colon cells (HT-29), breast cells or better known as adenocarcinoma (MCF-7) by colossymetry sulforhodamin B. The ethyl acetyl acetyl fraction of black tea-based kombucha contains dimethyl 2-(2-hydroxy-2-methoxypropilidene) malonate and vitexin at concentrations of 100 $\mathrm{g} / \mathrm{mL}$, thus causing cytotoxic effects in cells 786-O (human renal carcinoma) and U2OS (human osteosarcomoma), significantly. It also reduces invasion or attack on cell and cell motility in A549 (human lung carcinoma), U2OS and 786-O cells, as well as reduce the 
activity of matrix metaloproteinase-2 (MMP-2) and MMP-9 in cell 786-O and MMP-2 activity in cell A549 ((Jayabalan et al., 2011).

Lifolization in kombucha conducted in research conducted by Srihari et al., 2013, concluded that scoby kombucha extract was able to reduce survival in prostate cancer cells significantly by lowering the regulation of expression of angiogenesis stimulators such as matrix metalloproteinase, cyclooxygenase-2, interleukin8, endothelial growth factor, and human inducible factor- $1 \alpha$.

Some of the mechanisms that may be accepted by kombucha efficacious as anti-cancer both cellular and molecular include the following; Inhibits the occurrence of mutations in genes, inhibits cancer cell proliferation or division, induces apoptosis or programmatic cell death in cancer cells, and stops metastatic processes (Jayabalan et al., 2011). The benefits of kombucha, which has been revealed as a source of antioxidants, antibacterial sources, and anticancer sources, have the potential to conduct a study in producing halal probiotic drug and cosmetic preparations combined with plants that have the appropriate phytochemical character as antibacterials.

\section{Benefits Of Chemical Components In Kombucha That Have The Potential As Raw Materials For Halal Drugs And Cosmetics}

Kombucha is a conventional biotech product of probiotics produced through fermentation. Some of the components contained in it are vitamins, minerals, enzymes, and organic acids. The components contained in it are also beneficial for increased immunity, antioxidants, intestinal microflora recovery that can cause the digestive system to be optimal, as well as antihypertension (Wistiana and Zubaidah, 2015). Polyphenols are the main components contained in kombucha so it can be used as a functional drink, medicinal raw materials, and also cosmetics. The components contained in kombucha so that the author highly recommends as the main raw material in the manufacture of halal drugs and cosmetics in the biotechnology perspective include the following :

a) Lactic Acid

Lactic acid is one of the components contained in kombucha and is mostly stored in the form of $\mathrm{L}(+)$ Lactate so it is useful in restoring the digestive system, immune system, and as an indicator of cancer.

b) Acetic Acid

Acetic acid or already known as vinegar acid with the molecular formula $\mathrm{CH} 3 \mathrm{COOH}$ is one of the components contained in kombucha and plays an important role as a natural preservative, as a producer of aroma typical of kombucha

c) Malic Acid

Malic acid is one of the components contained in kombucha and plays an important role as a detoxification for the body 
d) Oxalic Acid

Oxalic acid is one of the components contained in kombucha and plays an important role as a preservative naturally, supporting cells in producing energy for the body.

e) Gluconic acid

Gluconic acid is one of the components contained in kombucha and plays an important role as an antimicrobial, especially from the yeast type Candida sp.

f) Butyric acid

Butyric acid is one of the components contained in kombucha and plays an important role as an antimicrobial especially in fighting infections derived from yeast with the help of gluconic acid.

g) Nucleic acid

Nucleic acid is one of the components contained in kombucha and plays an important role as an improvement in the cell regeneration process, so it has the potential to be developed in the direction of antiaging.

h) Amino acids

Amino acids are one of the components contained in kombucha and play an important role as the formation of proteins, especially antibodies to fight antigen attacks both bacterial and viral, cell division, and restoration of tissue damaged by exposure to free radicals.

i) Enzyme

Enzymes are one of the components contained in kombucha and play an important role as biocatalysts, accelerating biochemical reactions in the body, so as to improve and even restore the body functionally.

j) Vitamin

Vitamins are one of the components contained in kombucha in the form of B vitamins, and C. Symbiosis or combination of bacteria and yeast in kombucha has been able to be proven in producing vitamins. Thiamine which is a type of vitamin B1 and plays a role in carbohydrate metabolism in synthesizing energy, riboflavin is a type of vitamin B2 and plays a role in the mechanism of amino acid formation, Niacin is a type of vitamin B3 and plays a role in fat metabolism and lowering bad cholesterol or known as Low Density Lypoprotein (LDL), increases good cholesterol or known as HDL (High Density Lypoprotein) pridoxin is a type of vitamin B6, Cyanocobalamin is a type of vitamin B12 and acts as a role in metabolizing cells between the body, vitamin C, and polyphenols. (Firdaus et al., 2020).

\section{Bioinformatics Method As One Of The Design Of Medicinal And Cosmetic Raw Materials Based On Gene Expression.}

Bioinformatics is one of the fields of computational or informative biotechnology that is multidisciplinary. Bioinformatics is one of the methods in silico born from a clump of biology, medical, mathematics, statistics, and computer science that supports biological data both to identify diseases or genetic disorders, the design of raw materials vaccines, drugs, 
cosmetics, even functional foods that generally serve to restore body balance due to exposure to diseases that actually take a very long time to be researched with other approaches both in vitro (outside the body of a living being) or in vivo (in the body of a living thing using a test animal of a standard). Bioinformatics is one of the sciences born also from a family of informatics, artificial intelligence, chemistry, and biochemistry that aims to provide solutions to biological problems both at the cellular level and even to the molecular level (Pramana et al., 2018).

Another opinion on the definition of bioinformatics is a method of mathematics, statistics, and computing that aims to solve biological problems by utilizing sequences or sequences of DNA and Amino Acids contained or contained information in it. Raza (2012), Bioinformatics has been widely used and developed in other fields, especially to solve problems clinically, identify new disease agents diagnosis of recent diseases and even the discovery of raw materials for drugs in silico or dry lab. One of the bioinformatics analysis is gene expression, a number of genes that can be developed or utilized as determinants to measure their levels using various techniques such as Microaray.

Microaray is a technology that is used in measuring the level of gene expression found in a particular cell or tissue. Microaray appears in the form of a chip or microscope slide containing a series of tissue samples, cells, proteins, DNA, and RNA (Hovatta et al., 2005). Microaray technology is commonly used for genotyping on large scale, gene expression profiles, genomic hybridization, and stabilization among other bioinformatics application development. Microaray itself is one of the techniques born on the development or combination of technology and science fields such as mechanics, micro-manufacturing, chemistry, behavior or behavior of DNA, microfluids, enzymes, optics, and bioinformatics (Dufva, 2009). The data contained in the microarray can be utilized to Detect and classify disease tissue in humans. So that microarrrays are able to produce gene expression containing information on genes that can then be adapted to a disease (Trevino et al., 2007) that have been detected in silico as an initial screening to be proven through the development of research in vitro and in vivo.

Gene expression is a mechanism of transcription of DNA in the inner cell or nucleus into RNA (Madigan et al., 2008). DNA, also known as deoxyribonucleic acid, is one of the nucleic acids that play an important role in storing genetic information. The information in DNA is stored in code form consisting of four chemical bases: adenine (A), guanine $(\mathrm{G})$, cytosine $(\mathrm{C})$, and thyaine (T). The DNA sequence that encodes proteins is called genes, proteins are controlling the physical properties of cells such as the color of the eyes or hair. Unlike DNA, RNA is a single strand that is only 75-5000 nucleotides long. A cell contains several types of RNA: messenger RNA (mRNA), transfer RNA (tRNA), and ribosomal RNA (rRNA) (Bolstad, 2004). 
Gene expression can in principle be done in-vitro, especially at the mRNA level using the real-time PCR method, and protein levels with elisa (Enzyme Linked Immunoosorbant Assays) method which in principle looks for various drug findings, cosmetics that require special biological data on each specimen to be removed. The indicator is that if gene expression has increased from a disease problem, it can be ascertained that the raw materials of drugs and cosmetics are not able to provide solutions to the repair of certain diseases that have been damaged at the genetic level, while the indicator is if gene expression decreases from a disease problem then it can be ascertained that the raw materials of drugs and cosmetics are able to provide solutions to the improvement of certain diseases that have been Damage at the genetic level. Of course, by involving certain cells that cause a disease that causes cells and molecules to be damaged from genetically modified plants as raw materials for drugs and cosmetics that have been done through in silico, in vitro (gene expression), and in vivo tests. So it takes a cooperation with the pharmaceutical field to always make standardization, and the determination of secondary metabolite levels of a genetically modified plant to be developed in various formulations and pharmaceutical preparations both drugs and cosmetics that until now have not been widely developed by biotechnologists to always cooperate in the field of medicine, pharmacy, agriculture (nutritional science and food technology).

\section{CONCLUSION}

Kombucha with a low alcohol content category and potential as a source of antioxidants, antibacterials, and anticancers based on koperative exposure is feasible to develop on the manufacture of halal medicinal and cosmetic raw materials in a biotechnological perspective. The initial development stage to make drug and cosmetic raw materials from this product should be done in silico or bioinformatics which plays an important role to solve the problem of a disease to then be developed at the next level that is more complex, namely the in vitro and in vivo stages.

\section{REFERENCES}

Adnan M, Khan S, Kazmi A, Bashir N, Siddique R. COVID-19 infection : Origin , transmission, and characteristics of human coronaviruses. J Adv Res. 2020;24:91-98. doi:10.1016/j.jare.2020.03.005.

Adriani L, Mayasari. N, Kartasudjana, A.R. 2011. The Effect Of Feeding Fermented Kombucha Tea On HDL, LDL, And Total Cholesterol Levels In The Duck Bloods. J. Biotechnology in Animal Husbandry 27 (4), p 1749 - 1755. Doi: 10.2298/BAH110479A.

Al-Kalifawi, E. J. 2014. Antimikrobial Activity of Kombucha (KH) Tea against. Bacteria Isolated From Diabetic Foot Uleer. International Journal for Sciences and Technology, 9 (1), 49 - 56. https://doi.org/10.12816/0010111. 
Bolstad, B. M. (2004). Low level Analysis of High density Oligonucleotide Array Data : Background, Normalization and Summarization. University Of California.

Borkani. R.A, D. Monir and R. Zahra. 2016. Study of the Antibacterial Effect of Green and Black Kombucha Teas and Synergitic Effect Againts Some Foodstuff. International Journal of Advanced Biotechnology and Research. 7 (3), pp. 1741 - 1747.

Cetojevic-Simin DD, Bogdanovic GM, Cvetkovic DD, Velicanski AS. 2008. Antiproliferative and antimicrobial activity of traditional kombucha and Satureja montana L. Kombucha. J BUON 133:395-401.

Chofidah, A.I, Danu, M.D, Rosyidah. I.H. 2019. Uji Aktivitas Antibakteri Kombucha Rosela (Hibiscus sabdariffa L) Terhadap Bakteri Escherichia coli dan Staphylococcus aureus. Journal of Pharmaceutical Care - Anwar Medika. 2 (1). doi: http://dx.doi.org/10.36932/jpcam.v2i1.17.

Dufva, M. (2009). DNA Microarrays for Biomedical Research. switzerland: Springer.

Firdaus S, Indah A, Isnaini L, Aminah S. 2020. The Kombucha Sebagai Minuman Fungsional dengan Berbagai Bahan Dasar The. Prosiding Seminar Nasional Unimus. 3.e-ISSN :2654 - 3168

Gaggìa, F., Baffoni, L., Galiano, M., Nielsen, D. S., Jakobsen, R. R., Castro-Mejía, J. L., Bosi, S., Truzzi, F., Musumeci, F., Dinelli, G., \& di Gioia, D. 2019. Kombucha beverage from green, black and rooibos teas: A comparative study looking at microbiology, chemistry and antioxidant activity. Nutrients, 11(1). https://doi.org/10.3390/nu11010001.

Goh, W.N., A. Rosma, B. Kaur, A. Fazilah, A.A Karim, and R. Bhat. 2012. Fermentation of Black Tea Broth (Kombucha): I. Effects of Sucrose Concentration and Fermentation Time on Yield of Microbial Cellulose.

Hasan A.E.Z, D. Mangunwidjaja, T.C Sunarti1, O. Suparno, A. Setiyono. 2013. Optimasi Ekstraksi Propolis Menggunakan Cara Maserasi dengan Pelarut Etanol 70\% dan Pemanasan Gelombang Mikro Serta Karakteristiknya sebagai Bahan Antianker Payudara. Bogor: Institut Pertanian Bogor.

Herwin, Kosman, R., \& Fitriani. 2013. Analisis Kadar Alkohol Produk Kombucha Daun Permot (Passiflora foetida L.) Asal Makassar Sulawesi Selatan Secara Kromatografi Gas. As-Syifaa,05(02), 112-118. http://jurnal.farmasi.umi.ac.id/index.php/assyifaa/article/view/52

Hovatta, I., Kimppa, K., Lehmussola, A., Pasanen, T., Saarela, J., Saarikko, I., . . . Wong, G. 2005. DNA Microarray Data Analysis. Scientific Computing.

Jakubczyk, K., Kałdú Nska, J., Kochman, J., \& Janda, K. 2020. Chemical Profile and Antioxidant Activity of the Kombucha Beverage Derived from White, Green, Black and Red Tea. Antioxidants, 9(447), 1-15. https://doi.org/10.3390/antiox9050447. 
Jayabalan R, Subathradevi P, Marimuthu S, Sathishkumar M, Swaminathan K. 2008. Changes in Free-radical Scavenging Ability of Kombucha tea during fermentation. Food Chemistry.

Jayabalan R, Chen PN, Hsieh YS, Prabhakaran K, Pitchai P, Marimuthu S, Thangaraj P, Swaminathan K, Yun SE. 2011. Effect of solvent fractions of kombucha tea on viability and invasiveness of cancer cells - characterization of dimethyl 2-(2-hydroxy2-methoxypropylidine) malonate and vitexin. Indian J Biotechnol 10:75-82.

Kapp, J. M., \& Sumner, W. (2019). Kombucha: a systematic review of the empirical evidence of human health benefit. Annals of Epidemiology, 30(2), 66-70. https://doi.org/10.1016/j.annepidem.2018.11.001.

Khaerah, A., \& Akbar, F. (2019). Aktivitas Antioksidan Teh Kombucha dari Beberapa Varian Teh yang Berbeda. Seminar Nasional LP2M UNM, 0(0), 472-476. https://ojs.unm.ac.id/semnaslemlit/article/view/11466.

Khaleil. M.M, Ellatif. S.A, Soliman.M.H, Elzarik.Abd. E.S, Fadel. M.Sh. 2020. A Bioprocess Development Study of Polyphenol Profile, Antioxidant and Antimikobial Activities of Kombucha Enriched Psidium guajava L. Journal of Microbiology, Biotechnology and Food Sciences. Open Access.

Khaira, K. 2010, Menangkal Radikal Bebas dengan Anti-Oksidan. Jurnal Sainstek, 2(2). 183 $-187$.

Kim, J., \& Adhikari, K. (2020). Current Trends in Kombucha: Marketing Perspectives and the Need for Improved Sensory Research. Beverages, 6(1), 1-19. https://doi.org/10.3390/beverages6010015.

Madigan, M. T., Martinko, J. M., V, D. P., \& Clark, D. P. (2008). Brock Biology of Microorganisms (12th Edition). San Fransisco: Benjamin Cummings.

Mangela, O., Ridhay, A. \& Musafira. 2016, Kajian Aktivitas Antioksidan Ekstrak Daun Tembelekan (Lantana camara L) Berdasarkan Tingkat Kepolaran Pelarut. Jurnal Reset Kimia Kovalen. 2(3). 16-23.

Nguyen. K.N, Dong. N.T.N, Nguyen. H.T, Le. P.H. 2015. Lactic acid bacteria : promosing supplements for enhanching the biological activities of Kombucha. Springer Open Journal doi: 10.1186/s40064-015-0872-3.

Parwata, A. O. M. I. 2016. Antioksidan. Bahan Ajar. Universitas Udayana. Bali.

Pramana, S., Yuniarto, B., Mariyah, S., Santoso, I., \& Nooraeni, R. (2018). Data Mining dengan R. Bogor: IN MEDIA.

Pratiwi, A., \& Aryawati, R. (2012). Pengaruh Waktu Fermentasi Terhadap Sifat Fisik dan Kimia pada Pembuatan Minuman Kombucha dari Rumput Laut Sargasssum sp. I Maspari Journal, 04(1), 131-136. https://doi.org/10.36706/MASPARI.V4I1.1438.

Pure. A.E, Pure. M.E. 2016. Antioxidant and Antibacterial Activity of Kombucha Beverages Prepared using Banana Peel, Common Nettles and Black Tea Infusions. Applied Food Biotechnology. 3 (2) : 125 - 130. Journal homepage: www.journals.sbmu.ac.id/afb. 
Raza, K. (2012). Application of Data Mining in Bioinformatics. Indian Journal of Computer Science and Engineering, 114-118.

Rezaldi. F, T. Opik, Fadillah. M.F, Rochmat. A, Humaedi A, Fadhillah. F. 2021. Identifikasi Kandidat Vaksin Covid-19 Berbasis Peptida dari Protein Spike SARS CoV-2 Ras Asia Secara In Silico. Jurnal Biotek Medisiana. 10 (1) : $79-87$. https://doi.org/10.22435/jbmi.v10i1.5031.

Rudiana. T, Suryani. N, Anwar. H. 2021. Aktivitas Antioksidan dan Identifikasi Senyawa Metabolit Sekunder dari Ekstrak Dahu (Dracontomelon dao). Jurnal Kimia dan Terapannya. 5 (1) : 8 - 12. doi: 10.17977/um260v5i12021p008.

Sayuti, K. \& Yenrina, R. 2015, Antioksidan Alami Dan Sintetik. AU Press: Padang.

Suhardini, P.N., Zubaidah, E. 2016. Studi aktivitas antioksidan kombucha dari berbagai jenis daun Selama fermentasi. Jurnal Pangan dan Agroindustri Vol. 4 No 1 p.221-229.

Suranto, A. 2011. Dahsyatnya Sirsak Tumpas Penyakit. Pustaka Bunda, Jakarta.

Srihari T, Arunkumar R, Arunakaran J, Satyanarayana U. 2013a. Downregulation of signalling molecules involved in angiogenesis of prostate cancer cell line (PC-3) by kombucha (lyophilized). Biomed Prev Nutrit 3:53-

Tan, W. C., Muhialdin, B. J., \& Meor Hussin, A. S. (2020). Influence of Storage Conditions on the Quality, Metabolites, and Biological Activity of Soursop (Annona muricata. L.) Kombucha. Frontiers in Microbiology, 12(11), 110.https://doi.org/10.3389/fmicb.2020.603481.

Trevino, V., Falciani, F., \& Barrera-Saldana, H. A. (2007). DNA Microarrays : a Powerful Genomic Tools for Biomedical and Clinical Research. Molecular Medicine, 527-541.

Villarreal-Soto, S. A., Beaufort, S., Bouajila, J., Souchard, J. P., Renard, T., Rollan, S., \& Taillandier, P. 2019. Impact of fermentation conditions on the production of bioactive compounds with anticancer, anti-inflammatory and antioxidant properties in kombucha tea extracts. Process Biochemistry, 83(8), 44-54. https://doi.org/10.1016/j.procbio.2019.05.004.

Vita R, Overton JA, Greenbaum JA, et al. The immune epitope database ( IEDB ) 3 .n 0 . Nucleic Acids Res. 2015;43(October 2014):405-412. doi:10.1093/nar/gku938.

Vohra. B.M, Fazry.S, Sairi. F, Airianah. O.B. 2019. Effect of Medium Variation and Fermentation Time on the Antioxidant and Antimicrobial Properties of Kombucha. Malaysian Journal Of Fundamental and Applied Sciences. 15 (1) .Print ISSN : 2289 5981. Online ISSN : $2289-599 x$.

Wahdaningsih, S., Setyowati, E. P. \& Wahyuono, S. 2011, Aktivitas Penangkap Radikal Bebas Dari Batang Pakis (Alsophila glauca J. Sm). Majalah Obat Tradisional. 16(3). $156-160$. 


\section{IJMA: International Journal Mathla'ul Anwar of Halal Issues \\ Volume 1 Number 2: September 2021}

e-ISSN: 2775-6157

p-ISSN: 2807-2952

Yanti, A.R., Ambardini, S., Ardiansyah., Marlina, W.O.L. 2020. Aktivitas Antibakteri Kombucha Daun Sirsak (Annona muricata L.) Dengan Konsentrasi Gula Berbeda. Jurnal Berkala Sainstek. 8 (2) : 35 - 40. doi: https://doi.org/10.19184/bst.v8i2.15968.

Zubaidah, E., Ifadah, R. A., Kalsum, U., Lyrawati, D., Putri, W. D. R., Srianta, I., \& Blanc, P. J. (2019). Anti-diabetes activity of Kombucha prepared from different snake fruit cultivars. Nutrition and Food Science, 49(2), 333-343. https://doi.org/10.1108/NFS-072018-0201.

Zubaidah, E., Iastika, A.R., Widyaningsih, T.D., Febrianto, K. 2021. Immunomodulatory Activity of Black Tea Kombucha (Camellia sinensis) and Arabica Coffee Leaves Tea Kombucha (Coffee arabica) for Salmonella typhi-infected mice. International Conference on Green Agro-industry and Bioeconomy. IOP Conf. Series: Earth and Environmental Science 733 (2021) 012128. IOP Publishing. Doi:10.1088/1755$1315 / 733 / 1 / 012128$ 